\title{
PROGESTERONE LEVELS DURING THE OESTROUS CYCLE AND PREGNANCY IN THE CUIS, GALEA MUSTELOIDES
}

\author{
W. H. TAM* \\ Wellcome Institute of Comparative Physiology, \\ The Zoological Society of London, Regent's Park, London NW1 $4 R$ Y
}

(Received 8th October 1972)

\begin{abstract}
Summary. The progesterone levels in arterial plasma, luteal and non-luteal ovarian tissues of the cuis, Galea musteloides, were determined at various stages of the oestrous cycle and pregnancy, using gas-liquid chromatography with electron-capture detection. Plasma progesterone levels $(8$ to $18 \mathrm{ng} / \mathrm{ml}$ ) during the oestrous cycle are lower than those found in pregnancy where they stayed at 23 to $60 \mathrm{ng} / \mathrm{ml}$ during the first 15 days. They rose to $513 \mathrm{ng} / \mathrm{ml}$ at Day 26 and thereafter gradually declined to $108 \mathrm{ng} / \mathrm{ml}$ a few days before parturition (Day 53). Within $24 \mathrm{hr}$ after parturition, the level dropped to $23 \mathrm{ng} / \mathrm{ml}$. During pregnancy, the pattern of changes in plasma progesterone levels and even the absolute concentrations (except for the first 15 days) resembled those of the guinea-pig. Progesterone concentration and content in the Iuteal tissue differed from those of the latter species. The results indicated that the maximal activity of the CL occurred between 20 and 30 days' gestation, the timing of which was again similar to that in the guineapig. By comparison with other species, it was obvious that during gestation, both the guinea-pig and the cuis had very high plasma progesterone concentrations, and that gestation in these two animals could be divided into two phases according to these levels. The primary phase was the first 15 days when plasma progesterone was relatively low and the secondary phase was the latter half of gestation when the plasma progesterone concentration was at least fifteen times that of the primary phase. In both species, the establishment of the allantochorionic placenta occurred at the transition between these two phases when the plasma progesterone concentration was rising rapidly. The two phases probably represented stages where the requirement and metabolism of progesterone was widely different.
\end{abstract}

\section{INTRODUCTION}

The cuis, Galea musteloides, has only recently been studied in captivity (Weir, 1970). The gestation period is fairly short (53 days) and the oestrous cycle

* Present address: Department of Zoology, University of Western Ontario, London 72, Ontario, Canada. 
(about 22 days) is very variable (Rood \& Weir, 1970). Oestrus is evoked by the male (Weir, 1971). Since a breeding colony of these animals was available, it was of interest to investigate progesterone values for comparison with those reported for the guinea-pig, Cavia porcellus, as both are members of the Family Caviidae (Sub-order Hystricomorpha). This investigation forms part of a study of the cuis ovary being undertaken at the Institute. A preliminary account of the investigation of this species was given by Weir and others (see Rowlands, 1972, pp. 565-567). Progesterone concentration in plasma and ovarian tissue in the guinea-pig has been reported by Rowlands \& Short (1959), Heap \& Deanesly (1966), Heap, Perry \& Rowlands (1967) and Feder, Resko \& Goy (1968). The present study examines the progesterone levels in arterial plasma and in the CL of a few cyclic cuis and a small series of pregnant cuis.

\section{MATERIALS AND METHODS}

\section{Animals and sample collection}

All the animals used in this investigation were normal adults taken from the colony bred in the Institute by Dr B. J. Weir. Details concerning these animals and the way they were kept in the laboratory were given by Weir (1970). Stages of the oestrous cycle, or pregnancy, were dated from the day the vagina was fully open, or from the day mating was observed. The stages of pregnancy were also checked by the size of the fetuses after the mother was killed. Blood was removed from the left ventricle into a heparinized syringe when the animal was under diethyl ether anaesthesia. The plasma was separated by centrifugation and stored at $-17^{\circ} \mathrm{C}$ for progesterone determination. The CL were dissected and classified as current CL (of the present cycle or pregnancy) or old CL (of the previous cycle or pregnancy) according to their size (Table 1) and coloration, the younger CL being always paler in colour. The remnant of the ovary was termed residual tissue, which contained connective and interstitial tissue, follicles and possibly patches of old luteinized tissue. The preparation of the samples to this stage was carried out by Dr B. J. Weir and Dr I. W. Rowlands at the time of collection of material for histological studies. The ovarian tissue components were stored in either ethanol or methanol at $-17^{\circ} \mathrm{C}$ until extraction.

The plasma samples collected from the non-pregnant animals were between 1.8 and $4.2 \mathrm{ml}$ and those from pregnant animals, between 1.4 and $4.8 \mathrm{ml}$. The weight of the current CL samples for progesterone assay ranged between 4.0 and $85.4 \mathrm{mg}$. The residual tissue from a pair of ovaries weighed between 20 and $138 \mathrm{mg}$. Whenever parts of the ovaries of an animal were used for histology, the residual tissues from animals of similar physiological states were pooled so that each sample contained at least $20 \mathrm{mg}$ tissue to ensure that the total progesterone in it usually exceeded $25 \mathrm{ng}$. Pooling of this tissue did not invariably provide a minimum of $25 \mathrm{ng}$ progesterone, even when tissue was obtained from two or three animals.

\section{Extraction of progesterone}

Before extraction, approximately $10,000 \mathrm{~d} / \mathrm{min}(24 \mathrm{ng})$ of $\left[4-{ }^{14} \mathrm{C}\right]$ proges- 
Table 1. The progesterone concentration in arterial plasma, and the weight and progesterone levels of the corpora lutea in non-pregnant and pregnant Galea musteloides

\begin{tabular}{|c|c|c|c|c|}
\hline \multirow{3}{*}{$\begin{array}{c}\text { Physiological state } \\
\text { (days) }\end{array}$} & \multirow{3}{*}{$\begin{array}{c}\text { Plasma } \\
\text { progesterone } \\
(\mathrm{ng} / \mathrm{ml})\end{array}$} & \multicolumn{3}{|c|}{ Current corpora lutea } \\
\hline & & \multirow{2}{*}{$\begin{array}{l}\text { Weight } \\
(m g)\end{array}$} & \multicolumn{2}{|c|}{ Progesterone } \\
\hline & & & $\begin{array}{c}\text { Concentration } \\
(n g / m g)\end{array}$ & $\begin{array}{l}\text { Content } \\
(n g / C L)\end{array}$ \\
\hline $\begin{array}{c}\text { Cycle } \\
\text { Pro-oestrous } \\
2 \\
6 \\
9 \\
16\end{array}$ & $\begin{array}{r}10 \cdot 6 \\
14.3 \\
8.1 \\
17.9\end{array}-$ & $\begin{array}{c} \pm \\
2 \cdot 6 \pm 0 \cdot 5(7)^{*} \\
6 \cdot 3 \pm 1 \cdot 0(6) \\
-\end{array}$ & $\begin{array}{r}9 . \\
9 \cdot 0 \\
10 \cdot 9 \\
13 \cdot 3\end{array}$ & $\begin{array}{l} \\
24 \cdot 3 \\
78 \cdot 5 \\
81 \cdot 1\end{array}$ \\
\hline $\begin{array}{c}\text { Pregnant } \\
5 \\
6 \text { to } 10 \\
11 \text { to } 15 \\
16 \text { to } 20 \\
21 \text { to } 25 \\
26 \text { to } 30 \\
31 \text { to } 35 \\
36 \text { to } 40 \\
41 \text { to } 45 \\
46 \text { to } 50 \\
\text { Parturition } \dagger\end{array}$ & $\begin{array}{c}26 \cdot 6,22 \cdot 5 \\
32 \cdot 7 \pm 6 \cdot 6(3) \\
59 \cdot 7,23 \cdot 3 \\
125 \cdot 9,49 \cdot 6 \\
292 \cdot 7 \\
207 \cdot 7,512 \cdot 6 \\
274 \cdot 2 \\
251 \cdot 2,160 \cdot 9 \\
181 \cdot 3,84 \cdot 8 \\
107 \cdot 9 \pm 27 \cdot 6(3) \\
17 \cdot 4,29 \cdot 2\end{array}$ & $\begin{array}{c}2 \cdot 8 \pm 0 \cdot 6(4) \\
2 \cdot 7 \pm 0 \cdot 3(5) \\
4 \cdot 0 \pm 0 \cdot 8(6) \\
3 \cdot 3 \pm 0 \cdot 8(9) \\
6 \cdot 7 \pm 0 \cdot 8(5) \\
19 \cdot 1 \pm 2 \cdot 1(7) \\
8 \cdot 4 \pm 0 \cdot 4(5) \\
18 \cdot 4 \pm 1 \cdot 3(4) \\
21 \cdot 8 \pm 8 \cdot 8(5) \\
14 \cdot 1 \pm 1 \cdot 3(13) \\
\end{array}$ & $\begin{array}{l}27 \cdot 4,20 \cdot 7 \\
53 \cdot 1 \pm 9 \cdot 0(3) \\
64 \cdot 4,55 \cdot 3 \\
32 \cdot 3,6 \cdot 2 \\
60 \cdot 7 \\
20 \cdot 9 \pm 3 \cdot 9(3) \\
77 \cdot 0 \\
11 \cdot 7,3 \cdot 8 \\
9 \cdot 9,7 \cdot 7 \\
15 \cdot 7 \pm 9 \cdot 8(3) \\
-\end{array}$ & $\begin{array}{l}142 \cdot 5,58 \cdot 0 \\
156 \cdot 6 \pm 33 \cdot 2(3) \\
360 \cdot 6,127 \cdot 2 \\
210 \cdot 0,11 \cdot 2 \\
406 \cdot 7 \\
469 \cdot 2 \pm 130 \cdot 6(3) \\
646 \cdot 8 \\
230 \cdot 5,65 \cdot 0 \\
130 \cdot 7,434 \cdot 3 \\
256 \cdot 2 \pm 107 \cdot 1(3) \\
\quad \ldots\end{array}$ \\
\hline $\begin{array}{l}\text { Post partum, } \\
\text { lactating } \\
\text { I } \\
\text { Post coitum, not } \\
\text { pregnant } \\
4 \frac{1}{2}\end{array}$ & $22 \cdot 7 \pm 13 \cdot 3(3)$ & $8 \cdot 3 \pm 4 \cdot 0(3)$ & - & - \\
\hline
\end{tabular}

* Mean \pm S.E. The numbers in parentheses represent either the number of GL from which the mean was calculated, or the number of animals used in the progesterone determinations.

$\dagger$ In labour, but in dystocia.

terone $(58.5 \mathrm{mCi} / \mathrm{mmol})$ was added to the plasma for the calculation of recovery. The plasma was then rendered alkaline with $0.15 \mathrm{~m}-\mathrm{NaOH}$ and extracted with $4 \times 2$ vols diethyl ether. The ether was evaporated under nitrogen and the crude extract was ready for chromatography.

With the alcoholic preservative evaporated under nitrogen and after the addition of $10,000 \mathrm{~d} / \mathrm{min}(24 \mathrm{ng})$ of the same $\left[4-{ }^{14} \mathrm{C}\right]$ progesterone, the ovarian tissue was suspended in a small volume of $0.6 \mathrm{M}-\mathrm{NaOH}$ and homogenized in a small glass homogenizer. The suspension was made up to $25 \mathrm{ml}$ with 0.6 $\mathrm{M}-\mathrm{NaOH}$ solution and extracted with $4 \times 2$ vols diethyl ether. As the tissue extract was inevitably fatty, the ether was evaporated and the lipids removed by partition between light petroleum (b.p. 60 to $80^{\circ} \mathrm{C}$ ) and $70 \%$ methanol.

The $10,000 \mathrm{~d} / \mathrm{min}$ of $\left[4-{ }^{14} \mathrm{C}\right]$ progesterone, added to the samples as internal standard, represented an addition of $24 \mathrm{ng}$ progesterone and was always subtracted from the results.

\section{Determination of progesterone}

After extraction, the procedure for progesterone determination was the same for both plasma and ovarian tissue. Progesterone was isolated from the crude 
extract by thin-layer chromatography (TLG), using either the light petroleum (b.p. 60 to $80^{\circ} \mathrm{C}$ ) : benzene: ethyl acetate system $(1: 1: 4$, by vol) or the benzene: ethyl acetate system $(1: 1, \mathrm{v} / \mathrm{v})$. The isolated compound was then enzymatically reduced to 20 $\beta$-hydroxy-4-pregnen-3-one (Henning \& Zander, 1962). The product was then monochloroacetylated (Brownie, van der Molen, Nishizawa \& Eik-Nes, 1964) and the chloroacetate purified in the TLC system, benzene:ethyl acetate $(6: 1, \mathrm{v} / \mathrm{v})$. A known amount of testosterone monochloroacetate was added as gas-liquid chromatographic internal standard and a tenth aliquot of the sample was removed for radioactive counting to facilitate the calculation of recovery which was usually 20 to $30 \%$ at this stage, though higher recovery of 50 to $70 \%$ was sometimes obtained. The results were discarded if the recovery was lower than $20 \%$. Final quantification was by gas-liquid chromatography (GLC) with electron-capture detection (Tam, 1971), and the method for the calculation of results was based on that given by van der Molen \& Groen (1965). The results reported here were corrected for $100 \%$ recovery and the quantity of progesterone associated with the radioactive tracer was subtracted as mentioned above. The methods for the purification of chemicals used and the $\left[4-{ }^{14} \mathrm{C}\right]$ progesterone were also previously described (Tam, 1971).

\section{Precision experiments}

The ovarian tissue and plasma for some of the precision tests were obtained from the guinea-pig and chinchilla. The tissue was minced and the endogenous steroids removed by repeated extraction with warm methanol. Exogenous progesterone was added in small volumes (25 to $250 \mu \mathrm{l}$ ) of aqueous methanol. Time was allowed for adsorption and then the methanol was evaporated. The progesterone was assayed as mentioned in the previous section. When plasma was used, it was always divided so that one portion was used for the estimation of endogenous compound and the other portions for the determination of endogenous progesterone ( 1 to $20 \mathrm{ng} / \mathrm{sample}$ ) and added progesterone. After GLC quantification, the amount of exogenous progesterone in the sample was calculated by subtracting the endogenous compound. Duplicate determinations of endogenous progesterone in ovarian tissue and female plasma from various sources were also performed to give a further check on the precision of the assay method employed (Table 2).

\section{RESULTS}

\section{Weight of corpora lutea}

In this small series of animals, the number of CL was, on average, four and ranged between two and seven. The GL increased greatly in size during pregnancy and their number usually corresponded to that of the embryos. The mean weights of the CL are shown in Table 1. During the first 25 days' gestation, the increase in CL weight was very gradual and the $\mathrm{CL}$ of pregnancy were similar in size to those of the non-pregnant animals. However, between 26 and 30 days' gestation, there was a three- to sevenfold increase which was maintained for about 10 days. Then between 41 and 45 days' gestation, some 


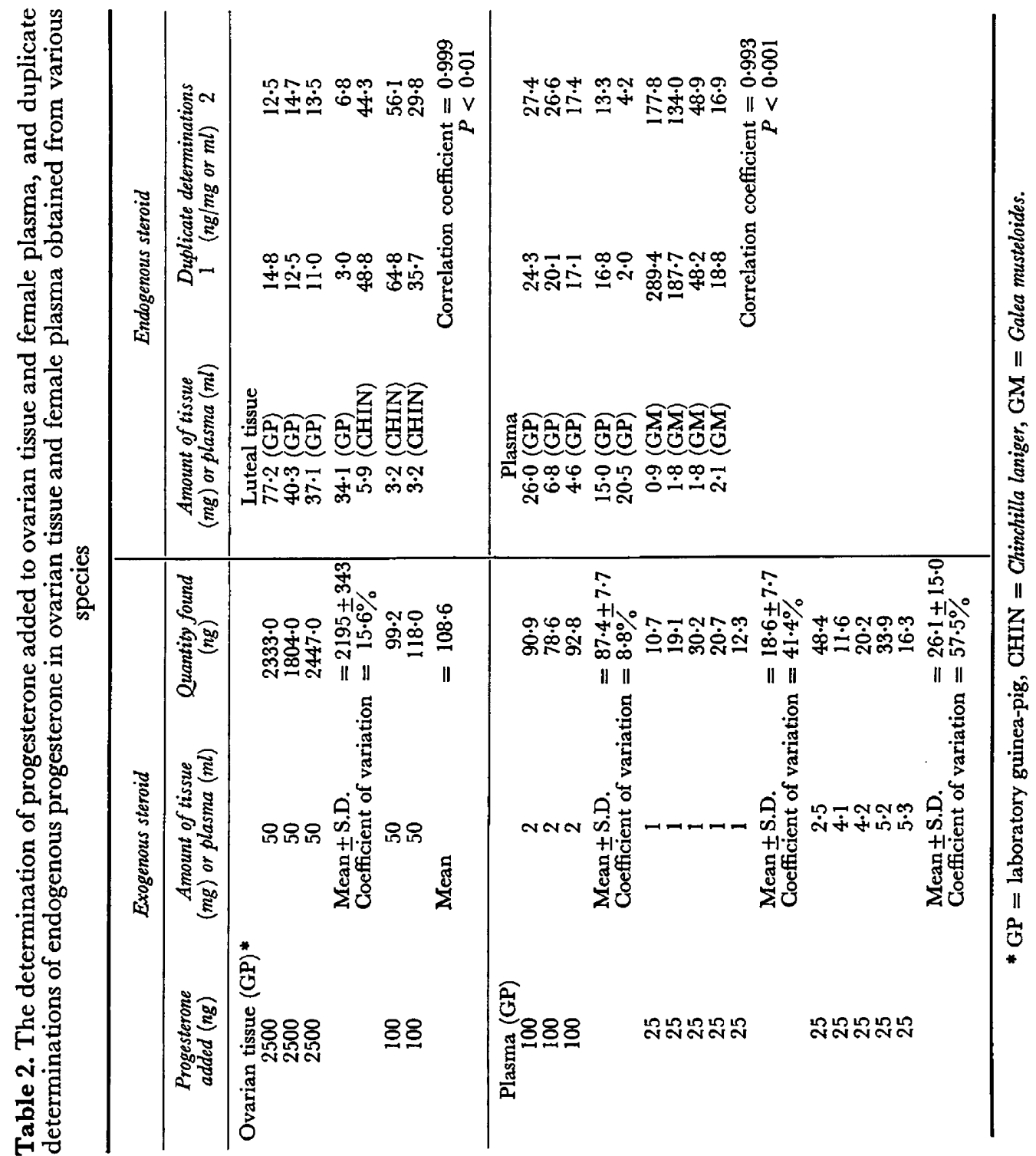


of the CL began to regress, whilst others maintained or even increased in weight. This resulted in great variation in weight as shown by the large standard errors. During the last few days of pregnancy, the CL regressed rapidly and $24 \mathrm{hr}$ after parturition their weight was similar to those in the non-pregnant and early pregnant cuis. These old CL persisted for a long time and were frequently still distinguishable up to 35 days of the next gestation, though their weight was negligibly small (about $0.8 \mathrm{mg} / \mathrm{CL}$ ). No increase in total ovarian weight was observed throughout gestation in this small series of animals.

\section{Precision experiments}

The results of the precision experiments and duplicate determinations are given in Table 2. In the determination of added progesterone, good accuracy

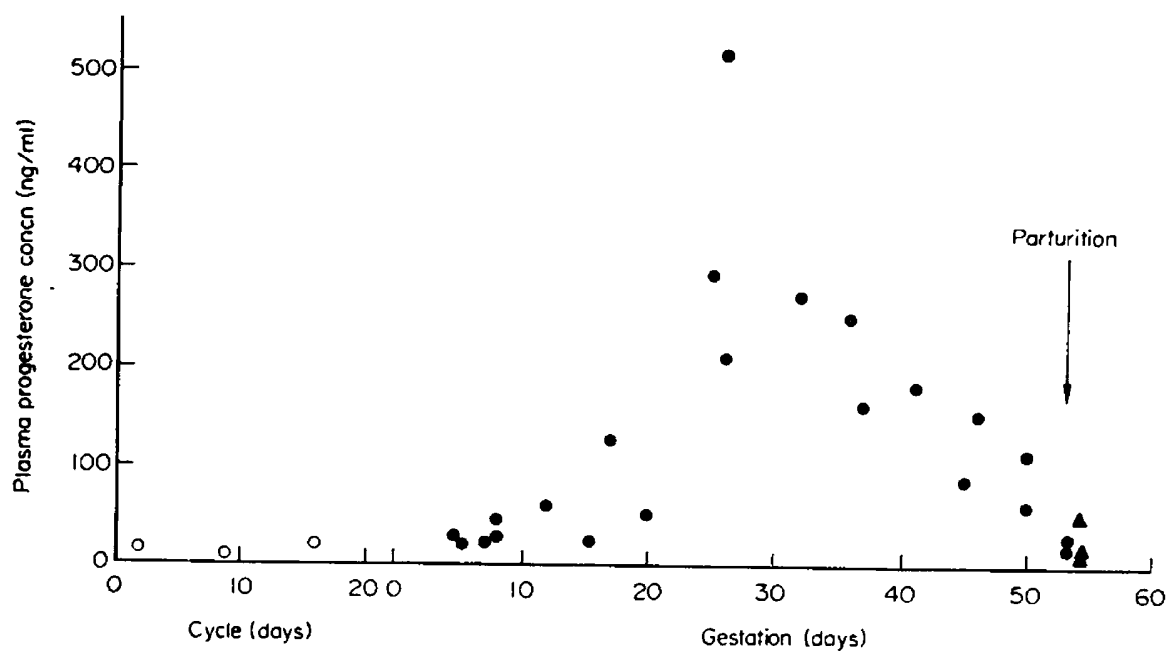

Text-FIG. 1. Progesterone levels in the arterial plasma of non-pregnant and pregnant Galea musteloides. $\bigcirc$, Cyclic; $\bullet$, pregnant; $\boldsymbol{\Delta}$, post-partum and lactating; the arrow indicates parturition at 53 days.

was obtained when $100 \mathrm{ng}$ of the compound were used, though the tendency was towards under-estimation. When $25 \mathrm{ng}$ progesterone were added to a sample of plasma, this tendency was more acute. However, there was good correlation between duplicate determinations of endogenous progesterone in both tissue and plasma even when the total amount in the sample was similar to those with $25 \mathrm{ng}$ progesterone added.

\section{Plasma and ovarian progesterone}

The progesterone concentration in arterial plasma and progesterone concentration and content, per CL, in the luteal tissue are given in Text-fig. 1 and Table 1. The progesterone levels in the non-pregnant animals studied were relatively low when compared to those of the pregnant animals. During the first 14 days' pregnancy, the progesterone concentration in plasma only increased slowly. It was only after Day 15 that it rose rapidly and reached a maximum of $513 \mathrm{ng} / \mathrm{ml}$ by Day 26. From then on, plasma progesterone concen- 
tration declined slowly and $24 \mathrm{hr}$ after parturition, it reached $23 \mathrm{ng} / \mathrm{ml}$. A comparable pattern of change was also found in the progesterone content of the CL of pregnancy (Table 1). Progesterone content was very variable after Day 30 because of the great variation in progesterone concentration between Days 30 and 40 and in CL weight between Days 41 and 45 (Table 1). The highest luteal progesterone concentration occurred between 11 and 15 days and then declined. Despite the persistency of the old CL, their progesterone concentration and content were negligible $(1.6$ to $7.0 \mathrm{ng} / \mathrm{mg}$ and 3.3 to $11.9 \mathrm{ng} / \mathrm{CL})$. The progesterone concentration of the residual tissue was also low and the progesterone content in the residual tissue of a pair of ovaries was approximately $100 \mathrm{ng}$, but could vary from less than $20 \mathrm{ng}$ to $400 \mathrm{ng}$, and could not be correlated with other changes in pregnancy.

\section{DISCUSSION}

The determination of progesterone added to ovarian tissue or plasma showed that down to $100 \mathrm{ng}$, very good accuracy (coefficient of variation $8 \cdot 8$ to $15 \cdot 6 \%$ ) could be obtained (Table 2). When only $25 \mathrm{ng}$ was used, the coefficient of variation increased and the tendency was towards under-estimation. The probable reason for this discrepancy is that there were two errors superimposed on one another as there were two estimations in each of these determinationsone to decide the amount of endogenous progesterone and the other, the total amount of progesterone. On the other hand, good correlation was observed for all duplicate determinations even when the total progesterone was approximately $35 \mathrm{ng}$ (Table 2). If the percentage mean deviation is calculated for the duplicate determinations, it is $12 \%$ for both tissue and plasma. As far as the Galea samples are concerned, with the exception of a few (notably the old luteal tissue), total progesterone in each was well over or approaching $100 \mathrm{ng}$. Thus, it can be taken that the precision of these determinations was of the order of 12 to $16 \%$.

The progesterone levels in G. musteloides present many interesting points when compared to those of the laboratory guinea-pig as reported by Challis, Heap \& Illingworth (1971). The patterns of change in plasma progesterone levels during gestation appear to be similar in the two species-relatively low concentrations are found during the first 15 days, highest levels are found at mid-pregnancy, and then somewhat lowered but yet sustained high levels are found at 51 to 60 days in the guinea-pig and 41 to 50 days in $G$. musteloides (Text-fig. 1). Even the concentrations are similar, except during the first 14 days when the progesterone concentration in Galea is about two to three times higher than that in the guinea-pig. It has also been reported that a second increase in plasma progesterone occurred in the guinea-pig during the last few days of gestation (Challis et al., 1971). Although this is not obvious in Galea, it is not necessarily excluded, as there were too few animals for such detailed study. Two interesting facts can be seen when the progesterone levels in plasma in these cavies are compared to those of other animals. (1) Plasma progesterone in other rodents such as the rat (Grota \& Eik-Nes, 1967; Hashimoto, Henricks, Anderson \& Melampy, 1968) and hamster (Leavitt \& Blaha, 
1970) increased almost to their highest levels right from the onset of pregnancy. This is not the case in cavies where plasma progesterone levels during pregnancy can be divided into two phases (see above). (2) The highest progesterone concentration found in the plasma of the guinea-pig and cuis during pregnancy is certainly very much higher than those found in many other animals such as the pregnant hamster $(25 \mathrm{ng} / \mathrm{ml}$; Leavitt \& Blaha, 1970), ewe (15 to $20 \mathrm{ng} / \mathrm{ml}$; Bassett, Oxborrow, Smith \& Thorburn, 1969; Fylling, 1970) and cow (8 $\mathrm{ng} / \mathrm{ml}$; Donaldson, Bassett \& Thorburn, 1970). Thus, not to mention the high level of $513 \mathrm{ng} / \mathrm{ml}$, even the progesterone concentrations $(6.3$ to $15 \mathrm{ng} / \mathrm{ml})$ during the first 15 days in guinea-pigs (Heap et al., 1967; Challis et al., 1971) and in G. musteloides ( 23 to $60 \mathrm{ng} / \mathrm{ml}$ ) are, in fact, high levels and the progesterone requirement during the first 15 days' gestation in both species of cavy is, therefore, by no means low compared to these animals.

The reason for the two phases in plasma progesterone levels in these two species during pregnancy remains to be explained. The causes for the large progesterone increase after the 15th day in the guinea-pig have been elegantly shown by the work of Illingworth, Heap \& Perry (1970) to be due to a decrease in its metabolic clearance rate and to a lesser extent to an increase in production by the CL. This decrease in metabolic clearance rate might be associated with an increase in progesterone-binding proteins in the circulation (Heap \& Deanesly, 1967). As pointed out by Heap et al. (1967) and Illingworth et al. (1970), these two levels of progesterone come before and after the development and establishment of the allantochorionic placenta in the laboratory guinea-pig. This is also true of $G$. musteloides where implantation occurred on the 6th day and the establishment of the allantochorionic placenta between 17 and 20 days' gestation (G. M. Roberts, personal communication). It is therefore clear that the two progesterone levels can be correlated to other events and that, in guinea-pig, the large increase in progesterone levels is accomplished by profound physiological changes. The progesterone levels possibly reflect marked differences in its requirement during different stages of pregnancy and the reason for these differences can only be explained by experiments on the hormone/target organ relationships in these cavies.

Despite differences in hormonal concentration and content, maximal luteal activity seems to occur at similar stages in gestation in the guinea-pig and the cuis. There were two peaks of high CL weight in Galea musteloides, one between 26 and 30 days' and the other between 41 and 45 days' gestation (Table 1), but there were great variations in weight at the second peak. Some of the CL were obviously on the decline and the weights were those which might have been extrapolated from the rate of decrease shown by animals at 36 to 40 and 46 to 50 days' gestation. Others showed large weight increases. Histological observations on the ovary of $G$. musteloides have been made and it was found that the CL appeared to be normal and active during Days 26 to 30 , but the weight increase during Days 41 to 45 was due to an accumulation of lipids in the cytoplasm of the luteal cells (see Rowlands \& Weir in Rowlands, 1972, pp. 566-567). Progesterone concentration in the luteal tissue was high during Days 11 to 15 (mean $=60 \mathrm{ng} / \mathrm{mg}$ ) and then decreased. By Day 30, it was about $21 \mathrm{ng} / \mathrm{mg}$ (Table 1 ). This decline in concentration was probably due to 
the considerable increase in the amount of luteal tissue that occurred at this time (Table 1) and not due to the inactivity of the luteal tissue (the progesterone content in GL even reached a maximum on Day 30). Maximal CL activity must therefore have occurred between Days 20 and 30 of gestation. The subsequent decrease in luteal progesterone concentration and content and the accumulation of lipids gave strong evidence that the activity of the CL had decreased. There was, therefore, good correlation between CL activity and plasma progesterone concentration, a situation reminiscent of that in laboratory guinea-pigs where luteal activity was maximal between Days 20 and 35 of gestation (Rowlands, 1956; Rowlands \& Short, 1959).

It is not known whether the placenta in Galea is active in the secretion of hormones for the maintenance of gestation. It may secrete progesterone and thus supplement the CL after their maximal activity is over, i.e. after Day 30 of gestation. Despite the persistence of the CL well into the next pregnancy, they were not active and their progesterone concentration was negligible. The progesterone of the residual tissue was also low but because of the large amount of such tissue in the ovary, the content might be considerable. It is, however, very possible that the progesterone might have come mainly from the ovarian follicles and partly from old luteal tissue and interstitial cells. It is difficult to assess what contribution the follicles and interstitial cells made towards the progesterone pool.

\section{Note added in proof}

After the work presented here was completed, Dr B. J. Weir ovariectomized some G. musteloides and found that pregnancy was not disturbed (B. J. Weir, personal communication). This showed, as in the laboratory guinea-pig, the possibility that the placenta was capable of secreting hormone(s) for the maintenance of gestation.

\section{ACKNOWLEDGMENTS}

The author expresses his gratitude to Dr I. W. Rowlands for his constant encouragement and interest in this work, and to him and to Dr B. J. Weir for the supply of all the biological material in these experiments. The author is also indebted to $\operatorname{Dr}$ M. A. Crawford for the use of his liquid scintillation spectrometer. The technical assistance of Mrs J. M. Gray is thankfully acknowledged. The work was supported by grants from the Ford Foundation and the Medical Research Council.

\section{REFERENCES}

Bassett, J. M., Oxborrow, T. J., Smith, I. D. \& Thorburn, G. D. (1969) The concentration of progesterone in the peripheral plasma of the pregnant ewe. F. Endocr. 45, 449.

Brownie, A. C., van der Molen, H. J., Nishizawa, E. E. \& Eik-Nes, K. B. (1964) Determination of testosterone in human peripheral blood using gas-liquid chromatography with electron capture detection. F. clin. Endocr. Metab. 24, 1091.

Challis, J. R. G., Heap, R. B. \& Illingworth, D. V. (1971) Concentrations of oestrogen and progesterone in the plasma of non-pregnant, pregnant and lactating guinea-pigs. F. Endocr. 51, 333.

Donaldson, L. E., Bassett, J. M. \& Thorburn, G. D. (1970) Peripheral plasma progesterone concentration of cows during puberty, oestrous cycle, pregnancy and lactation, and the effects of undernutrition or exogenous oxytocin on progesterone concentration. F. Endocr. 48, 599. 
Feder, H. H., Resko, J. A. \& Goy, R. W. (1968) Progesterone concentrations in the arterial plasma of guinea-pigs during the oestrous cycle. F. Endocr. 40, 505.

Fyllin, P. (1970) The effect of pregnancy, ovariectomy and parturition on plasma progesterone level in sheep. Acta endocr., Copenh. 65, 273.

GrotA, L. J. \& EIK-Nes, K. B. (1967) Plasma progesterone concentrations during pregnancy and lactation in the rat. F. Reprod. Fert. 13, 83.

Hashimoto, I., Henricks, D. M., Anderson, L. L. \& Melampy, R. M. (1968) Progesterone and pregn-4-en-20 $\alpha$-ol-3-one in ovarian venous blood during various reproductive states in the rat. Endocrinology, 82, 333.

Heap, R. B. \& Deanesly, R. (1966) Progesterone in systemic blood and placentae of intact and ovariectomized pregnant guinea-pigs. F. Endocr. 34, 417.

Heap, R. B. \& Deanesly, R. (1967) The increase in plasma progesterone levels in the pregnant guinea-pig and its possible significance. F. Reprod. Fert. 14, 339.

Heap, R. B., Perry, J. S. \& Rowlands, I. W. (1967) Corpus luteum function in the guinea-pig; arterial and luteal progesterone levels, and effects of hysterectomy and hypophysectomy. $\mathcal{F}$. Reprod. Fert. 13, 537.

HeNning, H. D. \& ZANDER, J. (1962) Verwendung von Hübeners $20 \beta$-Hydroxysteroid-dehydrogenase bei mikrochemischer Identifizierung und Trennung von Steroiden. Hoppe-Seyler's Z.physiol. Chem. 330, 31.

Illingworth, D. V., Heap, R. B. \& Perry, J. S. (1970) Changes in the metabolic clearance rate of progesterone in the guinea-pig. F. Endocr. 41, 409.

LeavitT, W. W. \& Blaha, G. C. (1970) Circulating progesterone levels in the golden hamster during the estrous cycle, pregnancy, and lactation. Biol. Reprod. 3, 353.

Rood, J. P. \& WEIR, B. J. (1970) Reproduction in female wild guinea-pigs. F. Reprod. Fert. 23, 393.

Rowlands, I. W. (1956) The corpus luteum of the guinea-pig. Ciba Fdn Colloq. Ageing, 2, 69.

Rowlands, I. W. (1972) Scientific Report of Zoological Society of London 1969-1971: Wellcome Institute of Comparative Physiology. F. Zool., Lond. 166, 562.

Rowlands, I. W. \& SHORT, R. V. (1959) The progesterone content of the guinea-pig corpus luteum during the reproductive cycle and after hysterectomy. F. Endocr. 19, 81 .

TAM, W. H. (1971) The production of hormonal steroids by ovarian tissues of the chinchilla (Chinchilla laniger). 7. Endocr. 50, 267.

van Der Molen, H. J. \& Groen, D. (1965) Determination of progesterone in human peripheral blood using gas-liquid chromatography with electron capture detection. F. clin. Endocr. Metab. 25, 1625 .

Werr, B. J. (1970) The management and breeding of some more hystricomorph rodents. Lab. Anim. 4, 83.

WEIR, B. J. (1971) The evocation of oestrus in the cuis, Galea musteloides. F. Reprod. Fert. 26, 405. 